DOI https://doi.org/10.18551/rjoas.2017-12.39

\title{
VALUE ADDED ANALYSIS ON PINDANG TUNA FISH BUSINESS IN PUGER DISTRICT OF JEMBER CITY
}

\author{
Suswandi Petrus Edi \\ Economic and Business Faculty, Jember University, Indonesia \\ E-mail: edisuswandi.fe@gmail.com
}

\begin{abstract}
The business of pindang tuna fishing is classified as traditional industry which is labor intensive. This industry has characteristics cultivated by small entrepreneurs, simple production techniques, and management handled by the family. Based on the above fact, this study aims to find the amount of value added to pindang tuna fish business in Puger District of Jember City, Indonesia. Data collection method was done by census method to all pindang tuna fish entrepreneurs who are still actively doing the activity at the time of this research. At the time of this study there were 35 fishing entrepreneurs still operating. The required data include the sale value of pindang tuna fish, the price of fresh tuna fish, the cost of auxiliary materials for making pindang tuna fish, the amount of production, the amount of working capital and the number of production equipment used in the process of pindang tuna fish. The result of value added analysis that by processing the tuna fish into pindang tuna fish was more profitable than the direct sale of fresh tuna fish. The reason is to process the fish first into the pindang fish will create value added in the form of capital gains plus the wages of labor.
\end{abstract}

\section{KEY WORDS}

Value added, pindang tuna fish, working capital, price.

The development of the industrial sector in the 21st century is aimed at strengthening the national economic structure. The development of the industrial sector is carried out with a strong and mutually supportive inter-sectoral linkages, expanding employment and business opportunities, as well as encouraging the development of various other development sector activities.

Most of the Indonesian population is in rural areas and livelihoods are mainly in the agricultural sector, while the contribution of the agricultural sector to Gross Domestic Product (GDP) and employment decreases, but the agricultural sector is still burdened to accommodate the workforce, while the industrial sector increases on Product Domestic Product (Ananta, 1993). Therefore, it is necessary for the development of industrial raw materials using agricultural products (agro industry). Increasing the development of agroindustry is expected to affect the development of the agricultural sector, so in addition to sufficient food needs the agricultural sector can support as a provider of raw materials for the industrial sector. Industrial development is a function of the main purpose to improve people's welfare, not an independent activity for just physical needs alone (Arsyat, 1992).

Jember city is one part of Indonesia territory where the population in rural areas is mostly in the agricultural sector, hence the development of industrial sector is needed, especially industrial sector which use raw material from agriculture sector (agroindustry), in order to increase people's incomes and open new job opportunities. As in the District of Puger Jember City which most of the population is farmers and fishermen, one of the opportunities to improve produtivitas in the agricultural sector is the development of fish processing into pindang fish. In addition to employment opportunities as well as the acquisition of additional income for local communities and avoid the risk of damage to fish. Increasing the amount of production is also necessary because with increasing production quantities will affect the prosperity of the population, through additional income and employment (Hasibuan, 1997). 
Pindang fish business is one of the traditional folk industry that generally use labor from within the family and also from outside the family. Those who become entrepreneurs of pindang tuna fish are not caught as fishermen. The labor used in pindang fish processing business in Puger is $3.53 \%$ of the family and the rest is $96.47 \%$ from outside the family.

Types of fish that are used as raw material of pindang fish is tuna fish. Production results are influenced by the season, the busy season takes place in the fourth month until the tenth month, while the quiet season takes place in the first month, second, third, eleventh and twelfth. The composition of fishery production in Puger is distributed $15 \%$ fresh fish, $5 \%$ kerupuk fish, $50 \%$ pindang fish and $30 \%$ of salted fish (Jember Fishery Service, 2016). Through the process of pindang fish is expected to create value added in the sense of acceptance of wages coupled with the benefits of capital owners (Rony, 1990).

In addition to creating value added, in the business of this pindang fish also at the same time can expand employment for the local population. By going through the process of the pindang fish industry is not just sold, but still needs to be processed. Processing fish into presrves tuna fish will be able to absorb labor and at the same time can raise the purchasing power of local communities. By raising people's purchasing power, it will increase the entrepreneurs' enthusiasm to increase their production.

In accordance with the objectives of national development, that is besides increasing the big and medium industries. In addition, it should continue to develop and preserve the lives of small and medium industries and traditional home industries. This is because most of Indonesia's population is located in rural areas, which generally work in the agricultural sector and small industrial sectors and household handicrafts.

In this business of pindang tuna fish, it is expected to be able to efficiently cost the business in order to obtain the benefits expected by the entrepreneurs, and also to create value added for local people to improve their welfare. Because with the creation of value added it will be able to strengthen the purchasing power of the community that will impact on increasing the daily needs of the local community.

Therefore, traditional small industries of pindang tuna fish are expected to increase income. Method of saving raw materials in the sense of avoiding waste and also need continuity in production by having stock of raw material at not season of fish.

The purpose of this study is to determine the amount of value added by processing the fresh tuna fish into pindang tuna fish. This, aimed in order to equitable income for the people of Puger District Jember City.

\section{LITERATURE REVIEW}

The research of fisheries industry in Indonesia is still very little compared to the research in other sectors outside the fishery sector. But the results of Harjono (1996) research on several factors that affect the profit and implication on the development of salted fish processing industry and pindang tuna fish in East Java showed that the fish is the main raw material for the pindang tuna fish business. The percentage is about 85 percent to 90 percent in the production cost structure derived from this component. While the implications of the availability of raw materials will determine the existence of the company both in the short and long term. Profits can be regarded as a stimulator for the growth and development of pindang tuna fish business, also much influenced by the price of raw materials and labor wages. While the family labor services in the production cost sector are not calculated the financial value. Based on the quantity of raw materials of fresh fish processed directly will determine the value of equipment investment, the value of working capital and the amount of labor. Viewed from the profit aspect of pindang tuna fish business, large scale is the scale that has the best profit level compared to small and medium scale.

The result of research of manurung (1989) on the socio-economic aspects of salted fish processing in Muncar found that the intensity is low, whether viewed from the quantity of business, the degree of participation and the technical capacity index and also there is an indication that the larger the scale, the lower the business intensity. To distinguish between the scale of business in the processing of pindang fish can be seen the amount of besek 
containing pindang fish on average each time the process that can be produced by each craftsman of pindang tuna fishing.

As a contribution or additional knowledge about pindang fish in this study trying to calculate how much value added that can be created by the business of pindang tuna fish. The value added can be defined as the wage of labor plus the profit of the capital owner (Rony, 1990). For example, cotton production is carried out by the agricultural sector. Cotton output by textile companies is an input to make cloth, then cloth is an input for convection company. In situations like this, when calculating the total product can occur repeated calculations, then to avoid repeated calculation should each production process is calculated separately in each company in each sector. Thus in calculating the value of production calculated only the added value of each sector, namely the difference between the value of production with the value of intermediate goods in the form of raw materials or basic materials, auxiliary materials and other auxiliary materials used to produce these products ( Deliarnov, 1995) are as follows:

$$
N T=N K-N M
$$

Note: NT = Value Added; NK = Output Value; NM = Input Value

Table 1 - Calculation of Added Value of Cotton Making Become Batik Clothes (Thousand Rupiah)

\begin{tabular}{|c|c|c|c|c|}
\hline Sector/Sub-sector & Production & Output Value & Inpun Value & Value Added \\
\hline \multicolumn{5}{|l|}{ Primary } \\
\hline - Agriculture & Cotton & 100 & 0 & 100 \\
\hline \multicolumn{5}{|l|}{ Secondary } \\
\hline - Spinning & Yarn & 150 & 100 & 50 \\
\hline - Weaving & Mori Fabric & 210 & 150 & 60 \\
\hline - Batik Activity & Batik Fabric & 280 & 210 & 70 \\
\hline \multicolumn{5}{|l|}{ Tertiary } \\
\hline - Tailor & Batik Clothes & 480 & 280 & 200 \\
\hline - Trading & Batik Clothes & 550 & 480 & 70 \\
\hline
\end{tabular}

Source: Introduction to Macro Economics.

Business scale is the average production that can be produced by every employer. Based on the distribution of business scale are criteria as follows:

Table 2 - Criteria of Business Scale On Pindang Tuna Fish Business in District Puger

\begin{tabular}{|c|c|c|c|}
\hline Business Scale & Code & The Number of Entrepreneurs & Average production per day (In Besek) \\
\hline Small & K & 14 & $<1.000$ \\
\hline Medium & S & 11 & $1.000-5.000$ \\
\hline Large & B & 10 & $>5.000$ \\
\hline Total & & 35 & \\
\hline
\end{tabular}

Source: Primary data is processed.

Production value is the result of the sale obtained based on the selling price. How to calculate it based on price per besek, and each average besek contains two tuna fish. The raw material used in this pindang business is the type of tuna fish and its purchase is measured by basket (cut), the contents of each basket 40 tuna type of fish. The amount of cash that to finance the pindang business, namely starting costs of raw materials, auxiliary materials, wage labor and marketing costs. Production equipment is equipment used to process fresh fish to become pindang fish. This pindang business appliance is used:

- Eser Plat is a place to boil fresh fish that can accommodate 600 besek per one process.

- The stove is a gas heater. Scale of business that uses the stove is medium and large scale business.

- The fireplace is a place to burn wood and also as a heater. The business scale that uses these stoves is mostly small-scale business. 
- Jedingan or tub that contains ice water to soak the tuna fish so as not to be quickly damaged and rot. Jedingan or tub is made of red stone and cement. Jedingan or tub is rectangular and placed near the place of boiled tuna fish.

Production capacity is the ability to produce an average per day for each entrepreneur of pindang tuna fish calculated based on the besek. The selling price is not always the same each time the market or varies, but in this study used is the direct selling price. The cost of raw material is the pice of fresh tuna that uses basket or cut size, which one basket contains 40 tuna fish as raw material for pindang. The typical pindang fish entrepreneurs in Puger District all use raw materials from tuna fish species.

\section{METHODS OF RESEARCH}

This research was conducted in Puger District Jember City. Selection of this location is done intentionally (purposive) with the consideration that this area of the most processed fish species into pindang is a type of tuna fish.

Population in this research is all entrepreneurs pindang still doing activity. The population is 35 entrepreneurs of pindang tuna fish. The method used is census. The census method is to take the entire population as the subject in this study. The data required in this study consist of primary and secondary data. Primary data collection was conducted through interviews with pindang entrepreneurs, workers and fish auction officers. Primary data required in this study is data that have links with working capital, the amount of production, production equipment and fishing season data.

Secondary data were taken from the relevant agencies of this study, such as the Puger District Office and the Statistical Office. Some of the secondary data required are geographical conditions, population conditions, employment conditions, educational conditions and number of registered pindang entrepreneurs. To answer the purpose of this research, that is value added analysis on the business of tuna fish in Puger, then used the formula as follows:

$$
\begin{gathered}
N T=N P-H B-H I P \\
\text { or } \\
N T=N K-N M
\end{gathered}
$$

Where:

$$
\begin{aligned}
& \text { NT = Value Added; } \\
& \text { NP = Average Production Value per Day; } \\
& \text { HB = Average Cost of Raw Material per Day; } \\
& \text { HIP = Average Input Price of Auxiliary Materials per Day; } \\
& \text { NK = Output Value (Selling Value or Output); } \\
& \text { NM = Input Value (Cost of Raw and Auxiliary Material or input). }
\end{aligned}
$$

\section{RESULT AND DISCUSSION}

The characteristics of the pindang business can be seen from five important aspects, namely respondent aspect, raw and auxiliary material aspects, production equipment aspect, employment aspect and business scale aspect. Most forms of companies in the business of pindang tuna fish is individual companies. Head of the company directly held by the head of the family. So the ability to run business management depends on the factors of education, age and experience. Most of the pindang entrepreneurs have a low education, namely primary school graduates. The age of the pindang business is ranged from 30 years to 60 years. Aspects of the pindang tuna fish business experience of existing in Puger on average they have been working for more than 15 years. This business is inherited, so the 
management capability of the pindang tuna fish is supported by the maturity of the business and the experience of his parents.

The main raw material in this business is the type of fresh tuna fish. To produce quality pindang need fresh tuna fish and pure salt. The size of the tuna must be uniform to keep the penetration (absorption) of salt in the pindang fish flesh to be perfect. To meet the needs of raw materials of tuna, done by: (1) fish auction system at TPI (fish auction), (2) direct bargain and (3) retail purchase. Regarding the way the payment can be made cash or payment behind after pindang sold. However, in Puger most direct payments are made.

For the price of raw materials there is a difference between the fish season and the quiet of the fish season. This happens because in the fish season, the fish production is abundant so the price of the fish becomes cheap around Rp 130.000 per basket. In quiet fish season then the price per basket up to Rp. 250,000. In the quiet fish season most entrepreneurs will reduce production because in addition to expensive, tuna fish raw materials also become rare.

Needs of auxiliary materials, salt, gas, firewood, ice cubes, besek (banana leaf), raffia rope, bamboo and claras can be obtained in the local area and usually the seller comes by himself at the place of business. The usefulness of auxiliary materials in this business of pindang tuna fish is as follows:

a. Salt, for flavor enhancers and keep long-lasting fish from the risk of damage, usually lasting 3 to 4 days.

b. Gas/Firewood, for heating.

c. Ice cubes, for soak the fish to keep the fish fresh and not decompose or damaged.

d. Besek (banana leaf), for pindang fish that is ready to be marketed.

e. Raffia straps, fot tie the joints with each of the contents of 14 besek (banana leaf).

f. Bamboo, to hold group of besek so as not to be easily damaged.

g. The cost of transporting raw materials from the fish auction place is quite cheap because it is bulk.

The production process of making pindang in puger generally use simple equipment and run by human power. The tool used is a test plate (a place to boil fish), gas stove (to boil fish), fireplace (heater using firewood), and tub (place sap fresh). For large scale business activities separated from households. For medium-scale and small-scale enterprises to become one with the household.

For labor wage system in pindang tuna fish business there is uniformity for all business scale. His wage system calculates the sum of the besek and renteng. For wage organizing and washing and boiling is used count per besek. To transport the production of pindang fish to trucks which are then marketed using renteng, where each renteng contains 14 besek.

The production value of the pindang business depends on the selling price of the production. The price of pindang fish is always changing and not the same on every shipment. In this study used to find the production value is the value of average production per day obtained by entrepreneurs. The average value of production obtained by small-scale enterprises amounted to Rp.2.520.000 to Rp.7.650.000, medium-scale business Rp.10.000.000 to Rp.50.000.000, and large-scale business Rp.60.000.000 to Rp .130.500.000. For average selling price received by small scale business Rp.9000 / besek, medium scale business and large scale business Rp.10.000 / besek. This price difference occurs because of different marketing areas. Large-scale and medium-sized enterprises marketing in Malang and Surabaya City. Medium small scale business marketing around Jember City.

In the technique of pindang tuna fish process between each business scale there is no difference. In general the way of making this commodity is described as follows:

a. Fish from TPI (fish auction place) directly inserted into Bak (jedingan) containing ice cubes. This aims to make the fish to be made fresh pindang.

b. The washing stage aims to keep the fish clean and not easily damaged.

c. Structuring in besek (banana leaf) which each contains two tuna fish and sprinkled with salt to taste. 
d. Boiling stage, which is stage where compilation of besek on ancak bamboo. The fullness is fully inserted into the teser plate containing salt water in a boil state and left for 40 minutes to 60 minutes.

e. The last stage is the lifting stage of the teser plate. Then drained and doused with warm water. It aims to keep pindang fish clean.

Table 3 - Value Added of Pindang Tuna Fish Business Average Per Day

\begin{tabular}{|c|c|c|c|c|c|}
\hline $\begin{array}{c}\text { Number of } \\
\text { Acquisitions }\end{array}$ & $\begin{array}{c}\text { I } \\
\text { Sale Value of } \\
\text { Pindang } \\
\text { (Rp) } \\
\end{array}$ & $\begin{array}{c}\text { II } \\
\text { Sale Value of } \\
\text { Fresh Tuna } \\
\text { (Rp) } \\
\end{array}$ & $\begin{array}{c}\text { III } \\
\text { Difference } \\
(\mathrm{I}-\mathrm{II}) \\
(\mathrm{Rp}) \\
\end{array}$ & $\begin{array}{c}\text { IV } \\
\text { Cost of Auxiliary } \\
\text { Material } \\
\text { (Rp) } \\
\end{array}$ & $\begin{array}{c}\text { Value } \\
\text { Added } \\
\text { (III-IV) } \\
(\mathrm{Rp}) \\
\end{array}$ \\
\hline 01 & 2.520 .000 & 1.820 .000 & 700.000 & 346.600 & 353.400 \\
\hline 02 & 2.700 .000 & 1.950 .000 & 750.000 & 351.000 & 381.000 \\
\hline 03 & 3.150 .000 & 2.270 .000 & 870.500 & 436.000 & 439.000 \\
\hline 04 & 3.600 .000 & 2.600 .000 & 1.000 .000 & 514.000 & 485.780 \\
\hline 05 & 4.050 .000 & 2.920 .000 & 1.125 .000 & 570.000 & 555.000 \\
\hline 06 & 4.050 .000 & 2.920 .000 & 1.125 .000 & 570.000 & 555.000 \\
\hline 07 & 4.500 .000 & 3.250 .000 & 1.250 .000 & 625.990 & 624.001 \\
\hline 08 & 4.950 .000 & 3.575 .000 & 1.375 .000 & 682.000 & 693.000 \\
\hline 09 & 5.400 .000 & 3.900 .000 & 1.500 .000 & 774.000 & 726.000 \\
\hline 10 & 5.850 .000 & 4.225 .000 & 1.625 .000 & 830.000 & 795.000 \\
\hline 11 & 6.300 .000 & 4.550 .000 & 1.750 .000 & 901.000 & 864.700 \\
\hline 12 & 6.750 .000 & 4.875 .000 & 1.875 .000 & 957.000 & 913.000 \\
\hline 13 & 7.200 .000 & 5.200 .000 & 2.000 .000 & 1.028 .000 & 972.000 \\
\hline 14 & 7.650 .000 & 5.525 .000 & 2.125 .000 & 1.083 .990 & 1.036 .010 \\
\hline 15 & 10.000 .000 & 6.500 .000 & 3.500 .000 & 1.192 .000 & 2.303 .000 \\
\hline 16 & 12.000 .000 & 7.800 .000 & 4.200 .000 & 1.403 .990 & 2.790 .920 \\
\hline 17 & 14.000 .000 & 9.100 .000 & 4.900 .000 & 1.652 .000 & 3.242 .910 \\
\hline 18 & 15.000 .000 & 9.750 .000 & 5.250 .000 & 1.757 .990 & 3.491 .650 \\
\hline 19 & 17.000 .000 & 11.050 .000 & 5.900 .000 & 1.987 .000 & 3.963 .000 \\
\hline 20 & 20.000 .000 & 13.000 .000 & 7.000 .000 & 2.355 .000 & 4.645 .000 \\
\hline 21 & 25.000 .000 & 16.250 .000 & 8.750 .000 & 2.954 .000 & 5.796 .000 \\
\hline 22 & 30.000 .000 & 19.500 .000 & 10.500 .000 & 3.516 .000 & 6.984 .000 \\
\hline 23 & 35.000 .000 & 22.750 .000 & 12.250 .000 & 4.103 .000 & 8.147 .000 \\
\hline 24 & 45.000 .000 & 29.250 .000 & 15.750 .000 & 5.268 .000 & 10.482 .000 \\
\hline 25 & 50.000 .000 & 32.500 .000 & 17.500 .000 & 5.809 .990 & 11.690 .010 \\
\hline 26 & 60.000 .000 & 39.000 .000 & 21.000 .000 & 7.032 .180 & 13.967 .820 \\
\hline 27 & 65.000 .000 & 42.250 .000 & 22.750 .000 & 7.625 .000 & 15.125 .000 \\
\hline 28 & 70.000 .000 & 45.500 .000 & 24.500 .000 & 8.224 .000 & 16.276 .000 \\
\hline 29 & 75.000 .000 & 48.750 .000 & 26.250 .000 & 8.756 .000 & 17.494 .000 \\
\hline 30 & 80.000 .000 & 52.000 .000 & 28.000 .000 & 9.290 .000 & 18.710 .000 \\
\hline 31 & 85.000 .000 & 55.250 .000 & 29.750 .000 & 9.826 .000 & 19.920 .300 \\
\hline 32 & 90.000 .000 & 58.500 .000 & 31.500 .000 & 10.390 .000 & 21.110 .000 \\
\hline 33 & 100.000 .000 & 65.000 .000 & 35.000 .000 & 11.620 .000 & 23.372 .600 \\
\hline 34 & 120.000 .000 & 78.000 .000 & 42.000 .000 & 13.932 .000 & 28.056 .600 \\
\hline 35 & 135.000 .000 & 87.750 .000 & 47.250 .000 & 15.532 .000 & 31.718 .000 \\
\hline Total & 1.221 .670 .000 & 799.045 .000 & 422.625 .000 & 143.895 .730 & 278.729 .270 \\
\hline
\end{tabular}

Source: Primary Data Analysis.

Pindang fish have characteristic of perishable goods. Therefore, pindang fish should be immediately marketed. Pindang fish from puger marketing mostly in Surabaya, Malang and Jember. The transportation used is a truck. Each truck has a capacity of carrying 5000 pieces of averages.

The production output for each entrepreneur does not have a brand. However, both the merchant and the consumer will know where the pindang comes from, that is, by the transport used (truck). Promotional activities are not done, but promotions can pass from one consumer to another. In addition, entrepreneurs must maintain the quality of goods. The way of marketing or distribution done by most of pindang fish entrepreneur in Puger, that is «Producer - Collectors - Retailer - Consumer». 
Production volume is measured by the amount of fish containing which can be average produced per day by company. In quiet fish season, entrepreneurs tend to reduce the amount of production. This is done because of the rareness and expensive of fresh tuna fish. In fish season, entrepreneurs will return to produce in accordance with the average ability per day.

Production volume can be used as a scale of business. Therefore, business scale measurement depends on the normal ability of the entrepreneur to produce average pindang fish per day during the fish season, because entrepreneurs can use their working capital during the fish season.

Value added has an important meaning for a production activity. The amount of added value is the average production value per day minus the average material use per day and the average auxiliary material cost per day. Value added is the profit of the employer plus the wage of labor.

The result of the value added of the business of pindang tuna fishing is shown in table 3. From table 3 that if fish are sold directly, will earn income amounting to Rp799.045.000. If the fish is processed first into pindang after it is on sale, will get Rp1.221.670.000. So there is a difference between sold directly and processed into pindang Rp1.221.670.000 Rp799.045.000 = Rp422.625.000.

The calculation of the value added shall be reduced the cost of the auxiliary materials required in the process of pindang tuna fish, as follows: Rp422.625.000 - Rp143.895.730 = Rp278.729.270. So the value added obtained by processing the fish become pindang is Rp.278.729.270. This is in line with the objectives of agro-industry development. The target of agro industry is to create value added.

\section{CONCLUSION}

Based on the results of this research analysis can be concluded that by processing the fish into pindang will be able to create value added in the framework of the distribution of people's income. The calculation results show that after the fish is processed into pindang can produce value added (gain of capital owner plus the wage of labor) equal to Rp278.729.270 per day. This shows that through the process of pindang fish more profitable than directly sold through fresh fish. Because by going through the process of pindang fish will require labor and avoid the risk of damage to fish and the equalization of public income. This situation is in accordance with the situation in the study area that the composition of the distribution of fisheries in the Puger area is $50 \%$ in pindang, $15 \%$ sold fresh, $30 \%$ salted fish and $5 \%$ for kerupuk.

\section{REFERENCES}

1. Ananta, Aris. 1993. Ciri Demografi Kualitas Penduduk dan Pembangunan Ekonomi. Jakarta: Lembaga Penerbit FE-UI.

2. Arsyad, Lincolin. 1988. Ekonomi Pembangunan. Yogyakarta: Penerbit STIE Yayasan Keluarga Pahlawan Negara.

3. Delliarnov. 1995. Pengantar Ekonomi Makro. Jakarta: Penerbit Universitas (UI Pers).

4. Harjono. 1996. Pembangunan Agribisnis dalam Pembangunan Ekonomi Nasional Menghadapi Abad Ke-21. Puslit IPB.

5. Hasibuan, Melayu SP. 1987. Ekonomi Pembangunan dan Peekonomian Indonesia. Bandung: CV. Amriko.

6. Manurung, 1989. Ekonomi Pembangunan dan Perencanaan. Jakarta: Rajawali Pers.

7. Rony, Mukhlisin A. 1990. Agroindustri Faktor Penunjang Pembangunan Pertanian Di Indonesia. Bandung: Pustaka Pribadi. 